\title{
Polymorphisms of Shank3 gene in Chinese Han Children with Autism Spectrum Disorders (ASD): A case- control study
}

\author{
Mei Jun Wang ${ }^{1,3}$, Fei Gui ${ }^{1}$, Xuan Jing ${ }^{1}$, Fu Sheng Huang ${ }^{1}$, Weipeng Wang ${ }^{2}$, Haiqing \\ $\mathrm{Xu}^{2}$, Hong Yan Chai ${ }^{1}$, Chunzi Liang ${ }^{1}$ and Jian Cheng $\mathrm{Tu}^{{ }^{*}}$ \\ ${ }^{1}$ Department of Clinical Laboratory \& Center for Gene Diagnosis, Zhongnan Hospital of Wuhan \\ University, Wuhan, china \\ ${ }^{2}$ Women and Children's hospital of Hubei province, Wuhan China \\ ${ }^{3}$ Department of Clinical laboratory, Shiyan People's Hospital, Affiliated to Hubei Medical College, \\ Shiyan China
}

Received: 15th March, 2017; Accepted: 6th April, 2017; Published: 29th July, 2017

*Corresponding author: Jian Cheng Tu, Department of Clinical Laboratory \& Center for Gene Diagnosis, Zhongnan Hospital of Wuhan University, Wuhan, china. Tel no: +86-13507119120, Fax: +86-27-6781-3497; E-mail: jianchengtu@whu.edu.cn

\begin{abstract}
This study investigated the co-relationship between single nucleotide polymorphisms (SNPs) variations of SHANK3 (SH3 and multiple ankyrin repeat domains 3) gene and childhood autism in Chinese Han populations. high-resolution method (HRM) were used to examine 11 polymorphisms of SHANK3 in 100 patients with ASD compared to 100 health controls. Risk estimates were expressed as odds ratio (OR) and 95\% confidence interval (CI). Overall there were significant differences in the allele distributions of rs9616816, rs6010061 and rs756638 (for rs9616816, OR=1.918, 95\%CI=1.2872.858, $\mathrm{P}=0.001$; for $\mathrm{rs} 6010061, \mathrm{OR}=0.517,95 \% \mathrm{CI}=0.291-0.919$, $\mathrm{P}=0.023$; for rs756638, OR=0.506, $95 \% \mathrm{CI}=0.296-0.866, \mathrm{P}=0.012$; respectively). Logistic regression analyses confirmed that these three SNPs were directly linked with significant risk of ASD. Our data indicate that SHANK3 gene polymorphisms may play a vital role in ASD genetic susceptibility in Chinese Han populations.
\end{abstract}

\section{Introduction}

The autism spectrum disorders (ASD), first reported in the early 1940sby psychiatristsis a severe neuropsychiatric disorder syndrome [1,2]. ASD is characterized by impairments of sociality and communication, lacking of reciprocal social interaction or responsiveness and repetitive or stereotyped behaviors (citation), the Onset of ASD mainly occurs in early childhood [3]. Despite the etiology of autism are largely unknown, it is widely accepted that autism is a multifactorial disease with a complex interaction of genetic and environmental factors [1,5,6]. In the past decades, though promising progress has been reported, ASD is still an urgent challenge for the public health [7].

Research proved that cause of ASD may reside in abnormalities at the synapse $[8,9]$. The SHANK3 gene, encodes a synaptic scaffolding protein [10]. In human beings, SHANK3 is expressed preferentially in cerebral cortex and cerebellum [11,12]. With its multiple protein interaction domains, this molecule directly or indirectly connects with neurotransmitter receptors and cytoskeleton proteins $[13,14]$. It also participates in the formation, maturation and enlargement of dendritic spines and is essential for the formation of functional synapse $[10,15,16]$. More importantly, a number of studies have been performed on SHANK3 polymorphisms with autism risk in different populations. However, the results were still controversial. Only one study of polymorphisms in SHANK3 found significant difference between ASD cases and controls [17], while the others were negative $[18,19,20]$.

The genetic variations of SHANK3 of ASD in Chinese Han population has been reported by Qin and Shao, however, it's not sufficient to demonstrate the co-relation between SHANK3 gene with other SNPs for the lack of diversity of the investigated SNPs. Therefore, further research about the co-relation between genetic variations of SHANK3 with ASD in Chinese Han populations is necessary and important. So far 21586 SNPs (according to NCBI) of SHANK3 gene has been reported. Accordingly, we selected 11 tag SNPs of SHANK3 gene in 100 cases and 100 controls to ascertain the association between this SNP and ASD susceptibility in Chinese Han children to gain a better understanding of the way it exerts its effect on ASD.

\section{Material and method}

\section{Participants}

A total of 100 ASD patients (76 males and 24 females, 2-12 years) and 100 healthy controls (69 males and 31 females, 2-12 years) were enrolled from Zhongnan Hospital of Wuhan 
University, Hubei Provincial Maternal and Child Health Hospital. All patients met DSM-IV diagnostic criteria for ASD. Written informed consent was obtained from each participant, and the study protocol was approved by the ethics committees of Zhongnan Hospital of Wuhan University.

\section{Genotyping}

Genomic DNA was extracted from the blood using a TIANamp Blood DNA Kit (TIANGEN, BeiJing, China). Eleven SNPs were selected from the HapMap HCB database with the criteria used in our SNP selection procedure [a minor allele frequency over 0.1 and tag SNPs with an $r^{2}$ value above 0.8 ] to examine the association between SHANK3 and ASD (Table 1). SNPs were genotyped by high-resolution melting of small amplicons on LightScanner 96 instrument (Idaho Technology, USA). Primer details and product lengths are shown in table S1. About $5 \%$ of the samples were randomly selected using direct PCR sequencing (Life Technologies Corporation, Shanghai, China) and the concordance was $100 \%$

Table 1: Characteristics of SNPs in shank3 gene cluster

\begin{tabular}{|c|c|c|c|c|}
\hline SNP & Position $^{1}$ & Minor allele & Major allele & MAF $^{2}$ \\
\hline rs2301584 & 51171497 & A & G & 0.223 \\
\hline rs2341011 & 51139635 & T & C & 0.321 \\
\hline rs41281537 & 51171667 & A & G & 0.058 \\
\hline rs5770820 & 51150473 & A & A & 0.253 \\
\hline rs5770992 & 51146139 & G & T & 0.108 \\
\hline rs6010061 & 51151724 & C & G & 0.417 \\
\hline rs6010065 & 51158017 & C & G & 0.490 \\
\hline rs756638 & 51171693 & A & G & 0.299 \\
\hline rs8137951 & 51165664 & A & G & 0.374 \\
\hline rs9616816 & 51123505 & A & T & 0.362 \\
\hline rs9616915 & 51117580 & C & 0.358 \\
\hline
\end{tabular}

${ }^{1}$ Position in basepairs was derived from dbSNP Build 137. Based on NCBI Human Genome Build 37.3 (November, 2014) of chromosome 22 ${ }^{2} \mathrm{MAF}$, minor allele frequency

Table S1. Amplification primers utilized in the genotype

\begin{tabular}{|c|c|c|c|c|}
\hline \multicolumn{2}{|c|}{ SNP } & \multirow{2}{*}{\begin{tabular}{l}
\multicolumn{1}{c}{ Primers $\left(\mathbf{5}^{\prime} \rightarrow \mathbf{3}^{\prime}\right)$} \\
GCTCTCAGCATGGAAAGA \\
TCCCATCACTGTTGTTTT
\end{tabular}} & \multirow{2}{*}{$\begin{array}{c}\text { product length (bp) } \\
57\end{array}$} & \multirow{2}{*}{$\frac{\operatorname{Tm}\left({ }^{\circ} \mathrm{C}\right)}{54.2}$} \\
\hline rs9616816 & $\begin{array}{l}\text { Forward } \\
\text { Reverse }\end{array}$ & & & \\
\hline rs6010061 & $\begin{array}{l}\text { Forward } \\
\text { Reverse }\end{array}$ & $\begin{array}{c}\text { GGAGTTTTCTCTCCATTCATATCTT } \\
\text { CTTAAGCACCATACTCC }\end{array}$ & 60 & 55 \\
\hline rs756638 & $\begin{array}{l}\text { Forward } \\
\text { Reverse }\end{array}$ & $\begin{array}{l}\text { TGTGTCTGTCCCTCATACC } \\
\text { CATGTGGTCCAGGCTGA }\end{array}$ & 102 & 54.5 \\
\hline rs6010065 & $\begin{array}{l}\text { Forward } \\
\text { Reverse }\end{array}$ & $\begin{array}{l}\text { TGGTACTTCTGCGTCGG } \\
\text { GCCAGTACAGGGCTCC }\end{array}$ & 89 & 59 \\
\hline rs2301584 & $\begin{array}{l}\text { Forward } \\
\text { Reverse }\end{array}$ & $\begin{array}{l}\text { GTTCCGCTTCACCTCCTT } \\
\text { GCCTCAGGACTGGAGCA }\end{array}$ & 69 & 57 \\
\hline rs41281537 & $\begin{array}{l}\text { Forward } \\
\text { Reverse }\end{array}$ & $\begin{array}{l}\text { GCTCAGTTGCCTGCTTG } \\
\text { CCGGTATGAGGGACAGA }\end{array}$ & 86 & 58 \\
\hline rs2341011 & $\begin{array}{l}\text { Forward } \\
\text { Reverse }\end{array}$ & $\begin{array}{l}\text { TCCGCTTCACCTCCTTT } \\
\text { GCCTCAGGACTGGAGCA }\end{array}$ & 67 & 56.8 \\
\hline rs5770992 & $\begin{array}{l}\text { Forward } \\
\text { Reverse }\end{array}$ & $\begin{array}{l}\text { TGGTCAGAATTTTCAC } \\
\text { TTATCTACATGGGGTT }\end{array}$ & 50 & 45 \\
\hline rs5770820 & $\begin{array}{l}\text { Forward } \\
\text { Reverse }\end{array}$ & $\begin{array}{l}\text { CTCTAGGGAGCAGGGAGAC } \\
\text { GACCAGCAGAAAGAAGCAA }\end{array}$ & 112 & 55 \\
\hline rs9616915 & $\begin{array}{l}\text { Forward } \\
\text { Reverse }\end{array}$ & $\begin{array}{l}\text { TCTCCACGACCACGC } \\
\text { CTCCTGCCAGCCATT }\end{array}$ & 52 & 63 \\
\hline rs8137951 & $\begin{array}{l}\text { Forward } \\
\text { Reverse }\end{array}$ & $\begin{array}{c}\text { ATGTCATACATACTATTTTTGCATT } \\
\text { TAGCACAAAGCCAGGAA }\end{array}$ & 55 & 53.6 \\
\hline
\end{tabular}




\section{Statistical methods}

Hardy-Weinberg Equilibrium and allele frequency distributions were analyzed by the chi-square test (SPSS, version 18.0). Each genotype of examined polymorphisms was assessed by logistic regression analyses under the additive (major homozygotes versus heterozygotes versus minor homozygotes), dominant (major homozygotes versus heterozygotes plus minor homozygotes) and recessive (major homozygotes plus heterozygotes versus minor homozygotes) models of inheritance after adjusting for sex and age, respectively (SPSS, version 18.0). Linkage disequilibrium (LD) analysis of SNPs and the haplotype association were analyzed using Haploview 4.2 and SHEsis software. P values less than 0.05 were considered statistically significant.

\section{Results}

\section{Genotype and Allele Frequencies}

No significant deviation from HWE was observed for all tested SNPs in the control groups ( $\mathrm{P}>0.05)$. As shown in table 2, logistic regression analysis revealed that $\mathrm{rs} 9616816$ was associated with ASD in both additive model [OR $=1.791,95 \% \mathrm{CI}(1.217-2.635), \mathrm{p}$ $=0.003]$ and recessive model $[\mathrm{OR}=2.569,95 \% \mathrm{CI}(1.382-4.774)$, $\mathrm{p}=0.003]$, rs6010061 and rs756638 were also associated with ASD in both additive model [OR $=0.550,95 \% \mathrm{CI}(0.320-0.946), \mathrm{p}=$ $0.031 ; \mathrm{OR}=0.510,95 \% \mathrm{CI}(0.296-0.878), \mathrm{p}=0.015]$ and dominant model [OR $=0.472,95 \%$ CI $(0.242-0.922), \mathrm{p}=0.028 ; \mathrm{OR}=0.461$, $95 \%$ CI (0.248- 0.858), $\mathrm{p}=0.014]$.

\begin{tabular}{|c|c|c|c|c|c|c|c|}
\hline SNP & genotype & $\begin{array}{l}\text { Control } \\
(n=100)\end{array}$ & $\begin{array}{l}\text { Case } \\
(n=100)\end{array}$ & $\begin{array}{l}\text { Allele } \\
\text { OR(95\% CI), } \\
\text { P value }^{1}\end{array}$ & $\begin{array}{l}\text { Additive } \\
\text { OR }(95 \% \text { CI }) \text {, } \\
\text { P value }^{2}\end{array}$ & $\begin{array}{l}\text { Dominant } \\
\text { OR(95\% CI }) \text {, } \\
\text { P value }^{2}\end{array}$ & $\begin{array}{l}\text { Recessive } \\
\text { OR }(95 \% \text { CI }) \text {, } \\
\text { P value }^{2}\end{array}$ \\
\hline \multirow[t]{3}{*}{ Rs9616816 } & GG & 31 & 19 & & & & \\
\hline & GA & 45 & 37 & & & & \\
\hline & AA & 24 & 44 & $\begin{array}{l}1.918(1.287- \\
2.858), \mathbf{0 . 0 0 1}\end{array}$ & $\begin{array}{l}1.791(1.217- \\
2.635), 0.003\end{array}$ & $\begin{array}{l}1.927(0.994- \\
3.737), 0.052\end{array}$ & $\begin{array}{l}2.569(1.382- \\
4.774), 0.003\end{array}$ \\
\hline \multirow[t]{3}{*}{ rs6010061 } & $\mathrm{TT}$ & 69 & 82 & & & & \\
\hline & CT & 25 & 15 & & & & \\
\hline & $\mathrm{CC}$ & 6 & 3 & $\begin{array}{l}0.517(0.291- \\
0.919), \mathbf{0 . 0 2 3}\end{array}$ & $\begin{array}{l}0.550(0.320- \\
0.946), 0.031\end{array}$ & $\begin{array}{l}0.472(0.242- \\
0.922), 0.028\end{array}$ & $\begin{array}{l}0.436(0.104- \\
1.818), 0.254\end{array}$ \\
\hline \multirow{2}{*}{ rs756638 } & GA & 34 & 21 & & & & \\
\hline & AA & 5 & 2 & $\begin{array}{l}0.506(0.296- \\
0.866), \mathbf{0 . 0 1 2}\end{array}$ & $\begin{array}{l}0.510(0.296- \\
0.878), 0.015\end{array}$ & $\begin{array}{l}0.461(0.248- \\
0.858), 0.014\end{array}$ & $\begin{array}{l}0.386(0.072- \\
2.064), 0.266\end{array}$ \\
\hline \multirow[t]{3}{*}{ rs6010065 } & GG & 28 & 37 & & & & \\
\hline & GC & 43 & 39 & & & & \\
\hline & $\mathrm{CC}$ & 29 & 24 & $\begin{array}{l}0.755(0.509- \\
1.119), 0.161\end{array}$ & $\begin{array}{l}0.788(0.543- \\
1.142), 0.208\end{array}$ & $\begin{array}{l}0.674(0.368- \\
1.233), 0.200\end{array}$ & $\begin{array}{l}0.764(0.403- \\
1.452), 0.412\end{array}$ \\
\hline \multirow[t]{3}{*}{ rs2301584 } & GG & 70 & 71 & & & & \\
\hline & GA & 26 & 27 & & & & \\
\hline & AA & 4 & 2 & $\begin{array}{l}0.896(0.526- \\
1.524), 0.684\end{array}$ & $\begin{array}{l}0.920(0.542- \\
1.562), 0.759\end{array}$ & $\begin{array}{l}0.992(0.536- \\
1.834), 0.979\end{array}$ & $\begin{array}{l}0.468(0.083- \\
2.637), 0.389\end{array}$ \\
\hline \multirow[t]{2}{*}{ rs41281537 } & GG & 79 & 73 & & & & \\
\hline & AA & 3 & 1 & $\begin{array}{l}1.194(0.666- \\
2.141), 0.552\end{array}$ & $\begin{array}{l}1.157(0.647- \\
2.068), 0.623\end{array}$ & $\begin{array}{l}1.355(0.703- \\
2.612), 0.365\end{array}$ & $\begin{array}{l}0.304(0.031- \\
3.002), 0.308\end{array}$ \\
\hline \multirow[t]{3}{*}{ rs2341011 } & $\mathrm{CC}$ & 49 & 40 & & & & \\
\hline & CT & 41 & 47 & & & & \\
\hline & $\mathrm{TT}$ & 10 & 13 & $\begin{array}{l}1.310(0.864- \\
1.987), 0.204\end{array}$ & $\begin{array}{l}1.309(0.861- \\
1.988), 0.208\end{array}$ & $\begin{array}{l}1.457(0.829- \\
2.560), 0.191\end{array}$ & $\begin{array}{l}1.325(0.548- \\
3.205), 0.532\end{array}$ \\
\hline \multirow[t]{2}{*}{ rs5770992 } & AA & 60 & 65 & & & & \\
\hline & $\mathrm{AG}$ & 32 & 28 & & & & \\
\hline
\end{tabular}




\begin{tabular}{|c|c|c|c|c|c|c|c|}
\hline & GG & 8 & 7 & $\begin{array}{l}1.189(0.769- \\
1.838), 0.437\end{array}$ & $\begin{array}{l}0.859(0.552- \\
1.338), 0.502\end{array}$ & $\begin{array}{l}0.805(0.453- \\
1.433), 0.462\end{array}$ & $\begin{array}{l}0.871(0.302- \\
2.512), 0.799\end{array}$ \\
\hline \multirow[t]{3}{*}{ rs5770820 } & GG & 23 & 33 & & & & \\
\hline & GA & 44 & 34 & & & & \\
\hline & $\mathrm{AA}$ & 33 & 33 & $\begin{array}{l}0.818(0.552- \\
1.212), 0.317\end{array}$ & $\begin{array}{l}0.829(0.578- \\
1.188), 0.307\end{array}$ & $\begin{array}{l}0.568(0.301- \\
1.073), 0.082\end{array}$ & $\begin{array}{l}0.991(0.548- \\
1.791), 0.975\end{array}$ \\
\hline \multirow[t]{3}{*}{ rs9616915 } & TT & 87 & 87 & & & & \\
\hline & $\mathrm{CT}$ & 12 & 11 & & & & \\
\hline & CC & 1 & 2 & $\begin{array}{l}1.077(0.506- \\
2.295), 0.847\end{array}$ & $\begin{array}{l}1.027(0.501- \\
2.104), 0.942\end{array}$ & $\begin{array}{l}0.940(0.407- \\
2.169), 0.885\end{array}$ & $\begin{array}{l}2.174(0.187- \\
25.238), 0.535\end{array}$ \\
\hline \multirow[t]{3}{*}{ rs8137951 } & GG & 55 & 58 & & & & \\
\hline & GA & 36 & 32 & & & & \\
\hline & AA & 9 & 10 & $\begin{array}{l}0.950(0.609- \\
1.481), 0.821\end{array}$ & $\begin{array}{l}0.955(0.627- \\
1.453), 0.828\end{array}$ & $\begin{array}{l}0.886(0.505- \\
1.554), 0.672\end{array}$ & $\begin{array}{l}1.116(0.430- \\
2.895), 0.822\end{array}$ \\
\hline
\end{tabular}

The minor $C$ allele of rs6010061 was associated with a lower risk of ASD [OR $=0.517,95 \% \mathrm{CI}(0.291-0.919), \mathrm{p}=0.023$ ] and the minor A allele of rs756638 was associated with a lower risk of ASD [OR $=0.506,95 \%$ CI $(0.296-0.866), p=0.012$ ], while carriers of the rs 9616816 A allele were associated with a higher risk of ASD [OR = 1.918, 95\% CI (1.287-2.858), $\mathrm{p}=0.001]$. Other SNPs, like rs6010065, rs2301584, rs41281537, rs2341011, rs5770992, rs5770820, rs9616915, and rs8137951, did not show any association with ASD.

\section{Linkage disequilibrium and haplotype analysis}

The Haploview 4.2 software was used for linkage disequilibrium analysis, and none of SNPs of this section are closely linked (D' and r2 > 0.85). The LD block of 11 SNPs were constructed (Figure 1). Table 3 presents the haplotype frequencies ( $\geq 3 \%$ ) of three positive polymorphisms in patients and controls. The most common haplotype A-T-G, G-C-G, G-T-A was assigned as the reference group in risk estimates. But the haplotype ATG may increase the risk of autism (OR: 2.702, 95\%:1.769 4.126, p

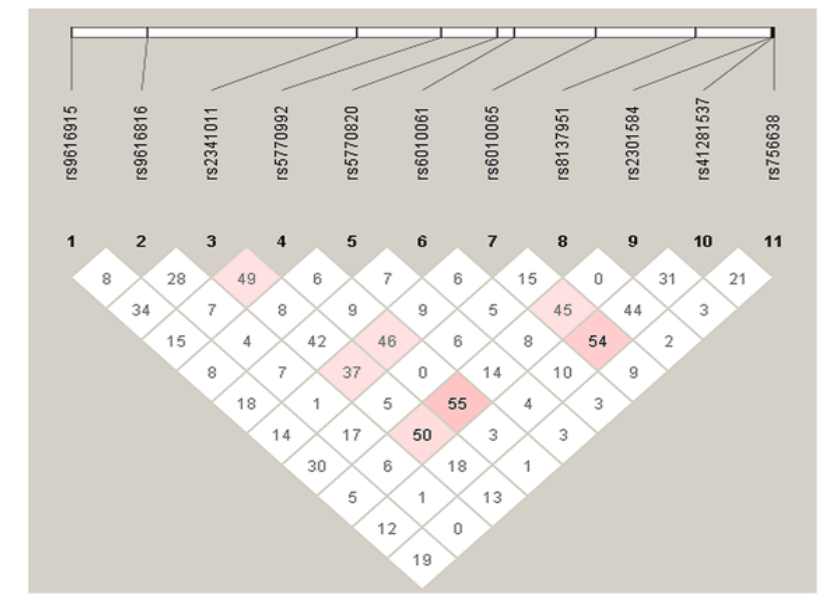
$<0.01$ ). Details are listed in table S1.

Table 3:Haplotype analysis in the control and the autism group

\begin{tabular}{|c|c|c|c|c|c|}
\hline Haplotypes & Cases (Freq.) & Controls (Freq.) & $\chi 2$ & P & Odds ratio (95\%CI) \\
\hline A C A & $2.90(0.015)$ & $2.70(0.013))$ & $/$ & $/$ & $/$ \\
\hline A C G* $^{*}$ & $12.17(0.061)$ & $16.97(0.085)$ & 0.875 & 0.35 & $0.695[0.324 \sim 1.494]$ \\
\hline A T A $^{*}$ & $12.52(0.063)$ & $20.88(0.104)$ & 2.326 & 0.13 & $0.570[0.274 \sim 1.183]$ \\
\hline A T G* & $97.41(0.487)$ & $52.45(0.262)$ & 21.676 & $3.3 \mathrm{E}-06$ & $2.702[1.769 \sim 4.126]$ \\
\hline G C A & $2.47(0.012)$ & $3.43(0.017)$ & $/$ & $/$ & $/$ \\
\hline G C G* $^{*}$ G T A $^{*}$ & $3.45(0.017)$ & $13.90(0.070)$ & 6.626 & 0.01 & $0.234[0.071 \sim 0.773]$ \\
\hline G T G* $^{*}$ & $7.11(0.036)$ & $17.00(0.085$ & 4.365 & 0.04 & $0.395[0.161 \sim 0.970]$ \\
\hline
\end{tabular}

\section{Discussions}

In this case-control study, we investigated the relationship between the 11 tag SNPs in SHANK3 gene and the risk of ASD in the Chinese population. Among the 11 SNPs, three SNPs (rs9616816,

rs756638, rs6010061) were found to be significantly associated with the risk of ASD in Chinese Han populations.

Sincethefirstreportof SHANK3mutationsinASD was published by Moessner et al. in 2007, several studies have been investigated 
the relationship between SHANK3 gene polymorphisms and ASD in different populations. Qin found none of the five SNPs was significant evidence $(\mathrm{P}<0.05)$ for preferential transmission of an allele by FBAT in all samples [18]; Sykes's data suggested that SHANK3 deletions may be limited to lower functioning individuals with autism[19]; Chien's research revealed that the 5 tag SNPs (rs2341011, rs5770992, rs5770820, rs6010065, and rs2301584) were not significant statistically [19 ]. However, there were few positive results of association between SHANK3 polymorphisms and ASD. Shao's study of rs9616915 polymorphisms in SHANK3 found significant difference between ASD cases and controls in Chinese Han population [17], while the others reported that SHANK3 might not represent a major susceptibility gene for ASD. The inconsistency with these pioneer works is possibly due to the difference of the sample size, individual genetic background, research design and environmental factors. However, the results were not fully consistent with previous reports. In the present study, we found the rs9616816, rs756638 and rs6010061 polymorphisms in the SHANK3 gene has a statistically significant association with ASD susceptibility and may affect the subject susceptibility toward autism in the Chinese Han population We established genotyping methods of 11 SNPs in the SHANK3 gene cluster by high-resolution melting and successfully found both the rs9616816 and rs6010061 were associated with ASD risk. The protective role of rs9616816 A allele against the risk of ASD suggested SHANK3 a possible candidate gene involved in the pathogenesis of ASD. Furthermore, Analysed with three models for genotype distributions, the association between SHANK3 SNPs (rs9616816, rs756638, rs6010061) and ASD remained significant after performing statistical adjustments for age and sex. This result supported previous reports that SHANK3 gene is a susceptible predictor of ASD risk factors [21,22,23,24,25].

Till now, little information is known about the role of SHANK3 gene in the diverse pathological processes to ASD children. SHANK3 gene, encodes a protein of the postsynaptic density of excitatory synapses, had been shown to bind to neuroligin, which, form a complex at glutamatergic synapses. In humans, SHANK3 was found expressed predominantly in cerebral cortex and cerebellum $[4,12,26]$. Durand and coworkers then identified two alterations in SHANK3 in subjects with an ASD, one is a de novo insertion of a $\mathrm{G}$ nucleotide in exon 21 of SHANK3, which leads to a frame-shift and presumed loss of function; the other was found in an unrelated family with a de novo deletion of terminal 22q13, with the breakpoint in intron 8 of SHANK3 [27]. Genetic and functional data implicate $S H A N K 3$ as a potential genic cause of ASD, which lead us to seek to further assess the involved polymorphisms and associated phenotypic outcomes. Recent studies indicate that autism is a disease of polygenic inheritance. Analysis of polymorphisms in the SHANK3 gene allows to effectively screen for autism risk [17]. Most previously reported studies narrowed on the mutations region. In our study, we covered the whole region of the SHANK3 gene, 11 tag SNPs, spreading in coding regions, 5' - and 3'- UTR regions, were selected and studied in our cohort. Positive SNPs, found only in intron (rs9616816 and rs6010061) and 3' untranslated region (3' UTR) (rs756638) of SHANK3 gene, indicated potential mechanism on the affection of the expression of SHANK3 by binding with transcription factors or micro RNA, could be altering the interaction of Shank with miRNAs.

The correlation between genotype and phenotype is very complicated, both genetic and environmental infaectors have significant effect on ASD. The further investigation is that positive SNPs how to regulate the expression of Shank3 gene by micRNA to reveal the role shank3 gene on the pathogenesis of ASD.

\section{Conclusions}

Our study supports that SHANK3 be a critical gene for the etiology of autism in Han Chinese population and three SNPs of SHANK3 gene potentially function as risky factor for ASD upon further validation and functional studies.

\section{Acknowledgements}

This work was supported by the National Natural Science Foundation of China and National Institutes of Health of United States of America (grant no.812111103), the Foundation of Hubei Provincial Population and Family Planning Commission (grant no.JS-2013002) and the National Natural Science Foundation of China (grant no.81472033). We express our deep appreciation to participants for their contribution to this study and all members of Center for Gene Diagnosis who collected and processed data for this project.

\section{References}

1. Abrahams BS, Geschwind DH. Advances in autism genetics:on the threshold of a new neurobiology. Nat Rev Genet. 2008;9(5):341-55. doi: $10.1038 / \mathrm{nrg} 2346$

2. H A. Die. "Autistischen Psychopathen" im Kindesalter. European Archives of Psychiatry and Clinical Neuroscience. 1944; 117: 76-136.

3.Lamb JA, Moore J, Bailey A, Monaco AP. Autism: recent molecular genetic advances. Hum Mol Genet. 2000;9(6):861-868.

4. Baron MK, Boeckers TM, Vaida B, Faham S, Gingery M, Sawaya MR. An architectural framework that may lie at the core of the postsynaptic density. Science. 2006;311(5760):531-535. doi: 10.1126/ science.1118995

5. Veenstra-VanderWeele J, Cook EH Jr. Molecular genetics of autism spectrum disorder. Mol Psychiatry. 2004;9(9): 819-832. doi: 10.1038/ sj.mp.4001505

6. Roberts JL, Hovanes K, Dasouki M, Manzardo AM, Butler MG. Chromosomal microarray analysis of consecutive individuals with autism spectrum disorders or learning disability presenting for genetic services. Gene. 2014; 535(1):70-8. doi: 10.1016/j.gene.2013.10.020

7. Newschaffer CJ, Curran LK. Autism: an emerging public health problem. Public Health Rep. 2003; 118(5):393-399. doi:10.1093/phr/118.5.393

8. Garber K. Neuroscience. Autism's cause may reside in abnormalities at the synapse. Science. 2007;317(5835):190-191. doi: 10.1126/ science.317.5835.190

9. O'Conno rEC, Bariselli S, Bellone C. Synaptic basis of social dysfunction: a focus on postsynaptic proteins linking group-I mGluRs with AMPARs and NMDARs. Eur J Neurosci. 2014;39(7), 1114-1129. doi: 10.1111/ ejn. 12510 
10. Tu JC, Xiao B, Naisbitt S, Yuan JP, Petralia RS, Brakeman P. Coupling of mGluR/Homer and PSD-95 complexes by the Shank family of postsynaptic density proteins. Neuron. 1999;23(3):583-592.

11. Lim S, Naisbitt S, Yoon J, Hwang JI, Suh PG, Sheng M, et al. Characterization of the Shank family of synaptic proteins. Multiple genes, alternative splicing, and differential expression in brain and development. J Biol Chem. 1999;274(41):29510-29518.

12. Bonaglia MC, Giorda R, Borgatti R, Felisari G, Gagliardi C, Selicorni A. Disruption of the ProSAP2 gene in a $t(12 ; 22)(\mathrm{q} 24.1 ; \mathrm{q} 13.3)$ is associated with the 22q13.3 deletion syndrome. Am J Hum Genet. 2001;69(2):261-268. doi:10.1086/321293

13. Ehlers MD. Synapse structure: glutamate receptors connected by the shanks. Curr Biol. 1999;9(22), R848-850.

14. Boeckers TM, Bockmann J, Kreutz MR, Gundelfinger ED. ProSAP/ Shank proteins - a family of higher order organizing molecules of the postsynaptic density with an emerging role in human neurological disease. J Neurochem. 2002;81(5):903-910.

15. Roussignol G, Ango F, Romorini S, Tu JC, Sala C, Worley PF, et al. Shank expression is sufficient to induce functional dendritic spine synapses in aspiny neurons. J Neurosci. 2005;25(14):3560-3570.doi: 10.1523/ JNEUROSCI.4354-04.2005

16. Durand CM, Betancur C, Boeckers TM, Bockmann J, Chaste P, Fauchereau F, et al. Mutations in the gene encoding the synaptic scaffolding protein SHANK3 are associated with autism spectrum disorders. Nat Genet. 2007;39(1):25-27. doi: 10.1038/ng1933

17. Shao S, Xu S, Yang J, Zhang T, He Z, Sun Z,et al. A commonly carried genetic variant, rs9616915, in SHANK3 gene is associated with a reduced risk of autism spectrum disorder: replication in a Chinese population. Mol Biol Rep. 2014;41(3): 1591-1595. doi: 10.1007/ s11033-013-3005-5

18. Qin J, Jia M, Wang L, Lu T, Ruan Y, Liu z. Association study of SHANK3 gene polymorphisms with autism in Chinese Han population. BMC Med Genet. 2009;10: 61. doi: 10.1186/1471-2350-10-61

19. Sykes NH, Toma C, Wilson N, Volpi EV, Sousa I, Pagnamenta AT. Copy number variation and association analysis of SHANK3 as a candidate gene for autism in the IMGSAC collection. Eur J Hum Genet.
2009;17(10): 1347-1353. doi:10.1038/ejhg.2009.47

20. Chien YL, Wu YY, ChiuYN, Liu SK, Tsai WC, Lin PI, et al. Association study of the CNS patterning genes and autism in Han Chinese in Taiwan. Prog Neuropsychopharmacol Biol Psychiatry. 2011;35(6):1512-1517. doi: 10.1016/j.pnpbp.2011.04.010

21. Gauthier J, Spiegelman D, Piton A, Lafreniere RG, Laurent S, St-Onge J. Novel de novo SHANK3 mutation in autistic patients. Am J Med Genet B Neuropsychiatr Genet. 2009;150B(3):421-424. doi: 10.1002/ ajmg.b.30822

22.Kolevzon A, Cai G, Soorya L, Takahashi N, Grodberg D, Kajiwara Y. Analysis of a purported SHANK3 mutation in a boy with autism: clinical impact of rare variant research in neurodevelopmental disabilities. Brain Res. 2011;1380:98-105. doi: 10.1016/j.brainres.2010.11.005

23. Soorya, Kolevzon A, Zweifach J, Lim T, Dobry Y, Schwartz L. Prospective investigation of autism and genotype-phenotype correlations in 22q13 deletion syndrome and SHANK3 deficiency. Mol Autism. 2013; 4(1):18. doi: 10.1186/2040-2392-4-18

24. Uchino S, Waga C. SHANK3 as an autism spectrum disorderassociated gene. Brain Dev. 2013; 35(2):106-10. doi:10.1016/j. braindev.2012.05.013

25. Leblond CS, Nava C, Polge A, Gauthier J, Huguet G, Lumbroso S, et al. Meta-analysis of SHANK Mutations in Autism Spectrum Disorders: a gradient of severity in cognitive impairments. PLoS Genet. 2014;10(9):e1004580. doi: 10.1371/journal.pgen.1004580

26. Meyer G, Varoqueaux F, Neeb A, Oschlies M, Brose N. The complexity of PDZ domain-mediated interactions at glutamatergic synapses: a case study on neuroligin. Neuropharmacology. 2004; 47(5), 724-733. doi: 10.1016/j.neuropharm.2004.06.023

27. Durand CM, Perroy J, Loll F, Perrais D, Fagni L, Bourgeron T, et al. SHANK3 mutations identified in autism lead to modification of dendritic spine morphology via an actin-dependent mechanism. Mol Psychiatry. 2012;17(1):71-84. doi: 10.1038/mp.2011.57

28. Veenstra-VanderWeele J, Cook EH Jr. Molecular genetics of autism spectrum disorder. Mol Psychiatry. 2004;9(9): 819-832. doi: 10.1038/ sj.mp. 4001505 